\title{
Linguistic aspects of studying phrasal verbs
}

Shokarova N. ${ }^{*}$

Kharkiv Specialised School № 11, Kharkiv, Ukraine

Received: $12.03 .2019 \quad$ Accepted: 16.04 .2019

\begin{abstract}
New phrasal verbs are coined in the language every day, and some of them become even more popular than their single-component synonyms. At the same time the frequency of their usage grows. A large number of phrasal verbs, changing its"nature", passes from one stylistic layer into another, receives new meanings and loses the old ones. Many phrasal verbs became a part of lexicon used in fiction. It attracts the interest of linguists in phrasal verbs now and in the past too and becomes the cause of the relevance of the current research. The phrasal verbs which are found in the novel by the American writer Jerome David Salinger "The Catcher in the Rye" (1951) were analyzed for the first time in this research. During the theoretical analysis of the literature a complex method of the research on this subject was used. Therefore, the definition was given to a concept of phrasal verbs and the existing approaches of their classification in terms of semantics were analyzed. 146 phrasal verbs were selected and checked by method of continuous selection in the dictionaries. As a result of the analysis of the first and second component of the phrasal verbs, by the means of the dictionary, the classification of verbs on the basis of already existing classification developed by linguists M. Celce-Murcia and D. Lassen-Freeman was created. Further, when studying the semantic component of the word, the meanings of both the verb and the second component of phrasal verbs were analyzed with the help of the method of the componential analysis. During the research the method of contextual analysis of phrasal verbs was used for the meanings of the verbs which occur in the novel. On the basis of the received results some additions were made to the above-stated classification, namely some nuances of already existing aspectual phrasal verbs group were complemented with a subcategory which received the name telicity. The phrasal verbs with the shade of meaning of a certain completeness of the action were added to this category.
\end{abstract}

Key words: Idiom, semantic unit, phraseological merging, phraseological unities, phraseological messages.

\section{Лінгвістичні аспекти вивчення фразових дієслів}

\author{
Шокарьова Н. С. \\ К3 «Харківська спеціалізована школа №11», Харків, Україна
}

\begin{abstract}
Анотація. Нові фрразові дієслова виникають в мові кожного дня, а деякі з них стають навіть більш популярними, ніж їх однокомпонентні синоніми. Разом з тим росте частота їх вживання. Велика кількість фразових дієслів, змінюючи своє «єство», переходить із одного стилістичного пласту в інший, отримує нові значення та втрачає старі. Багато фразових дієслів стали частиною лексики художньої літератури. Це викликає інтерес лінгвістів до фразових дієслів зараз та в минулому та обумовлює актуальність дослідження. У дослідженні були вперше розглянуті фрразові дієслова, що зустрічаються у творі американського письменника Джерома Девіда Селінджера «Ловець у житі» (1951). Під час теоретичного аналізу літератури було застосовано комплексний метод дослідження з даної теми. В результаті чого, було дане визначення поняттю фрразових дієслів та проаналізовані існуючі підходи їх класифікації з точки зору семантики. Методом суцільної вибірки були відібрані та перевірені у словниках 146 фразових дієслова. У результаті аналізу першого і другого компоненту фразових дієслів, за допомогою словника, було створено класифікацію дієслів на основі вже існуючої класифікації, що розроблена вченими-лінгівістами M. Celce-Murcia та D. LassenFreeman. Далі методом компонентного аналізу, під час вивчення семантичної складової слова, були проаналізовані значення як дієслова, так і другого компоненту фразових дієслів. Для дослідження фрразових дієслів методом контекстного аналізу були взяті дієслова саме в тих значеннях, які зустрічаються в романі. На основі отриманих результатів були внесені деякі доповнення у вищезазначену класифікацію, а саме доповнені деякі нюанси вже існуючої групи aspectual phrasal verbs підкатегорією, яка отримала назву telicity, до якої увійшли фразові дієслова зі значенням певної завершеності дії.
\end{abstract}

Corresponding Author: Shokarova Nataliia. Tel. +38(098)656-85-55. E-mail: shokarovanata@ukr.net. Kharkiv Specialised School № 11, 7 Vasylia Melnykova Street, City, Country, 61000.

Відповідальний автор: Шокарьова Наталія Сергї̈вна. +38(098)656-85-55. E-mail: shokarovanata@ukr.net. КЗ «Харківська спеціалізована школа №11», вулиця Василя Мельникова, 7, Харків, Харківська область, 61000 
Ключові слова: ідіома, семантична одиниця, фразеологічні зрощення, фразеологічні єдності, фразеологічні сполучення.

\title{
Лингвистические аспекты изучения фразовых глаголов Шокарева Н. С.
}

\author{
К3 «Харьковская специализированная школа №11», Харьков, Украина
}

\begin{abstract}
Аннотация. Новые фразовые глаголы возникают в языке каждый день, а некоторые из них становятся даже более популярными, чем их однокомпонентные синонимы. Вместе с тем растет частота их употребления. Большое количество фразовых глаголов, меняя свое «естество», переходит из одного стилистического пласта в другой, получает новые значения и теряет старые. Многие фразовые глаголов стали частью лексики художественной литературы. Это вызывает интерес лингвистов к фразовым глаголам сейчас и в прошлом и обусловливает актуальность исследования. В исследовании были впервые рассмотрены фразовые глаголы, встречающиеся в произведении американского писателя Джерома Дэвида Сэлинджера «Над пропастью во ржи» (1951). Во время теоретического анализа литературы были использованы комплексный метод исследования по данной теме. В результате чего, было дано определение понятию фразовых глаголов и проанализированы существующие подходы их классификации с точки зрения семантики. Методом сплошной выборки были отобраны и проверены в словарях 146 фразовых глагола. В результате анализа первого и второго компонента фразовых глаголов, с помощью словаря, была создана классификация глаголов на основе уже существующей классификации, разработанной учеными-лингивистамы M. Celce-Murcia и D. Lassen-Freeman. Далее методом компонентного анализа, при изучении семантической составляющей слова, были проанализированы значения как глагола, так и второго компонента фразовых глаголов. Для исследования фрразовых глаголов методом контекстного анализа были взяты глаголы именно в тех значениях, которое встречаются в романе. На основе полученных результатов были внесены некоторые дополнения в вышеуказанную классификацию, а именно дополнены некоторые нюансы уже существующей группы aspectual phrasal verbs подкатегорией, которая получила название telicity. B неё вошли фразовые глаголы со значением определенной завершенности действия.

Ключевые слова: идиома, семантическая единица, фразеологические сращения, фразеологические единства, фрразеологические сочетания.
\end{abstract}

\section{Bcmyn}

Фразові дієслова являють собою особливе, специфічне явище в англійській мові. Вони є продуктивною, динамічною та семантично насиченою групою англійської лексики. Прийнято вважати, що фразові дієслова частіше вживаються в розмовній англійській мові. Однак багато фразових дієслів стали частиною лексики художньої літератури. Це викликає інтерес лінгвістів до фразових дієслів зараз та в минулому. Багато мовознавців зверталися до питання дослідження фразових дієслів. Існує багато робіт присвячених характеристиці фрразових дієслів, їх структурі та значенням. Серед них є дослідження таких вчених-лінгвістів як О. І. Смирницького, Н. Н. Амосової,О. В. Куніна, С. В. Григор'єва, І. Є.Анічкова, В. М. Телії, Д. Поуві (J. Povey), Д. Болінджера (D. Bolinger), Р. Кверка (R. Quirk), Т. МакАртура (Т. MacArthur) та багато інших.

Нові фрразові дієслова виникають в мові кожного дня, а деякі 3 них стають навіть більш популярними, ніж їх однокомпонентні синоніми. Разом з тим росте частота їх вживання. Велика кількість фразових дієслів, змінюючи своє «єство», переходить із одного стилістичного пласту в інший, отримує нові значення та втрачає старі.

Meта роботи: $є$ аналіз та класифікація фразових дієслів з твору американського письменника Дж. Д. Селінджера «Ловець у житі» (1951) [2] з точки зору семантики.

\section{II Матеріал і методи дослідження}

Теоретичне значення роботи полягає у комплексному дослідженні поняття фразових дієслів за семантичними ознаками у романі Дж. Д. Селінджера «Ловець у житі». У результаті аналізу першого і другого компоненту фразових дієслів за допомогою словника, було створено класифікацію дієслів на основі вже існуючої класифікації, що розроблена вченими-лінгівістами M. Celce-Murcia та D. LassenFreeman (1999), та доповнені деякі нюанси значення у групі aspectual phrasal verbs. 
Різні лінгвісти та науковці дають власні визначення фразових дієслів. В цілому, погляди вченихлінгвістів, що займалися даним питанням можна розділити на дві групи.

Прибічники першої теорії вважають, що фразове дієслово $€$ семантичною одиницею, що складається з дієслова та прислівникової чи прийменникової частини. Таким чином, дослідник в області лінгвістики Джейн Поуві дає наступне визначення фразовому дієслову. «Фразове дієслово - це поєднання дієслова і адвербіальної або прийменникової частини, що є єдиною семантичною та синтаксичною одиницею та може бути вжито замість одного слова» [1, с. 9].

Російські та вітчизняні філологи зазначають, що фразові дієслова є характерним явищем для англійської мови, але зовсім відсутні в російській чи українській мовах. На думку лінгвістів К. $Є$. Голубкової та М. С. Переверткіна фразові дієслова - це «особлива форма словосполучення, що утворене шляхом додавання до монолексемного дієслова прийменникової частини - післялогу, в результаті чого значення початкового дієслова може повністю змінитися» [3].

Відомий американський лінгвіст Дуайт Болінджер визначає фразові дієслова як семантичні одиниці, що складаються з дієслова та частки. Він стверджує, що ця семантична одиниця має особливість, яка називається пов'язаністю (cohesion) [4, с. 153]. Його послідовник С.В. Григор'єв визначає фразові дієслова як багаточленні лексичні одиниці, що складаються з дієслів, які означають життєво необхідні поняття і мають високу частоту вживання, і прислівників, які означають напрям дії [5, C. 3].

Британській філолог Р. Кверк (R. Quirk) стверджує, що фразові дієслова складаються з дієслова та прислівника і функціонують як єдине ціле [6, с. 1150-1167].

Британський лінгвіст Ф. Р. Палмер (F. R. Palmer) вважає, що «фразове дієслово складається з 2 елементів: дієслова та прислівникової частки. Прислівникова частка - це прислівник, який слідує за дієсловом і вважається частиною дієслова. Прислівникова частка вважається суффіксом дієслівного кореня. Ця частка визначає напрям руху. У фразовому дієслові з ідіоматичним значенням важко визначити значення напрямку» [7].

Прибічники ж другої теорії розглядають фразові дієслова як фразеологічні одиниці. Дослідник О. І. Смирницький відносить фразові дієслова до фразеологічних одиниць та вважає, що з семантичної точки зору, фразеологічна одиниця може бути одновершинною, двовершинною, багатовершинною (тобто мати одне, або більше головних слів, навколо яких згруповані інші слова), а фразові дієслова це одновершинні фразеологічні одиниці [8].

Для О. В. Куніна ці сполучення (фразові звороти) володіють як рисами фразових одиниць, так і рисами складних слів [9, с. 274]. Компоненти фразових одиниць настільки пов'язані одне з одним, що значення цілого не виводиться із сукупності значень частин, що входять до її складу.

Існує безліч підходів для класифікації фразових дієслів. Професор А. В. Кунін, використовуючи класифікацію Шебалі, у своїй праці «Курс фразеології сучасної англійської мови», створив класифікацію, що заснована на семантичному принципі, тобто на ступені умотивованості компонентів фразових дієслів, на ступені їх спаяності. [10, с. 7] Лінгвіст розподіляв фразові дієслова на 3 групи:

1. Фразеологічні зрощення

Вони відрізняються високим ступенем спаяності компонентів і найменшим ступенем умотивованості. Буквальний їх переклад не має сенсу, тому вони потребують запам'ятовування.

Наприклад:

- hang around - "to wait or spend time somewhere, usually for no particular reason" [22] (бити байдики) [2, с. 4];

- flunk out - "to have to leave a school because your work is not satisfactory" [22] (провалити тест або екзамен) [2, с. 11];

2. Фразеологічні єдності.

Такі фразові дієслова складають більш чисельну групу. Вони мають середній ступінь умотивованості, ясну образність та переносне значення. У фразеологічних єдностях можна вгадати значення цілого вислову за значеннями його компонентів.

Наприклад:

- go over - "to move or travel towards someone or something" [22] (зайти до когось з візитом) [2, с. 1]; 
- wait around - "to stay in the same place and do nothing while you are waiting for something to happen, someone to arrive etc" [23] (чекати на когось) [2, с.55];

3. Фразеологічні сполучення.

Ці лексичні одиниці мають високий ступінь умотивованості. В даному випадку - це вільні сполучення дієслова та прислівника чи дієслова та прийменника, що реалізують свої номінативні значення.

Наприклад:

- look at - "to direct your eyes towards someone or something so that you can see them" [22] (дивитися на щось/когось) [ 2, с. 1];

- come back - "to return to a place" [22] (повертатися) [2, с. 3];

Не тільки фрілолог Кунін розглядав фразові діалоги як такі, що можна розподілити на 3 групи або категорії. Зокрема можна відокремити класифрікацію за М. Celce-Murcia та D. Lassen-Freeman (1999). Ці філологині використовують дещо інший принцип для розподілення фразових дієслів на три групи.

1. Literal phrasal verbs

Дієслово, що входить до цієї групи, зберігає своє значення, а також прислівник чи прийменник вживається у своєму буквальному значенні. Такі дієслова є найпростішими для розуміння та вивчення $[11$, c. 432-433].

До цієї категорії входять дієслова, що складаються з дієслова та прийменника, що вказує на напрямок дії (out, down, away, up, through).

Наприклад:

- stand up [2, c. 11] - "to be in an upright position on your feet; to get yourself into an upright position on your feet" [24];

- run away [2, c. 61] - "to leave a place or person secretly and suddenly" [24];

2. Aspectual phrasal verbs.

До другої категорії належать дієслова, значення яких не стовідсотково очевидне, але й не ідіоматичне. До цієї категорії входять дієслова, до яких певні частки (прийменники чи прислівники) додають нюанси значення. Вона, в свою чергу, також може бути розділена на підкатегорії, в залежності від семантичного внеску частки [11, с. 432-433].

Inceptive (інхоативні) (містять дієслова, що вказують на початок дії):

Використання часток off, up та out.

Наприклад:

- start back [2, c. 13] - "to begin returning to the place you came from" [23];

- start up [2, c. 75] - "to switch on a machine or engine, especially a motor vehicle" [22];

Continuative (термінативні) (містять дієслова, що вказують на продовження дії):

Вживання часток on та along з дієсловами, які означають продовження діяльності.

Наприклад:

- come along [11, c. 433].

Вживання частки through 3 дієсловами, що позначають діяльність, буде означати, що дія відбуватиметься від початку до кінця.

Наприклад:

- look through [2, c. 123] - "to look for something among a pile of papers, in a drawer, in someone's pockets etc." [23].

Вживання частки ашау додає дієслову нюанс «безтурботності».

Наприклад:

- work away [11, c. 433].

Вживання частки around підкреслює певну відсутність мети дії.

Наприклад:

- go around [2, c.27] - "to spend a lot of time with someone, going to different places and doing things" [22];

- move around [2, c. 9] - move around the place, doing nothing;

Completive (перфективні) (містять дієслова, що вказують на те, що дія завершена, тобто для позначення повної вичерпаності дії). 
Вживання частки up, out, off та down щоб показати, що дія завершена.

Наприклад:

- close up [2, c. 68] - "to lock the doors of a building or business" [22];

- tear up [2, c. 36] - "to destroy something such as a piece of paper or cloth by pulling it into pieces" [22];

3. Idiomatic phrasal verbs.

Ця група складається з дієслів, значення яких дуже складно або зовсім неможливо визначити зі значень окремих слів, з яких складаються фразові дієслова.

Наприклад:

- show up [2, c. 2] - "to arrive, especially at the place where someone is waiting for you" [23];

- get away with [2, c. 42] - "to manage to do something bad without being punished or criticized for it" [22];

Подібної думки дотримується D. Bolinger, який визначає ідіоматичні фрразові дієслова як такі, що не можуть бути перекладені за допомогою суми значень слів, з яких вони складаються. Наприклад, hang out.

Лінгвіст Р. Кверк також розподіляє всі фразові дієслова на три групи. Відмінністю є назви груп. Кверк розподілив фразові дієслова на free non-idiomatic, semi-idiomatic та highly idiomatic, але пояснення обрав дуже подібне до класифікації Куніна.

Деякі вчені-лінгвісти розподіляють всі фразові дієслова на дві основні групи. Британський лінгвіст та головний редактор лінгвістичного журналу English Today T. McArthur визначає, що фразові дієслова можуть бути розподілені на ті, що мають буквальне (literal) та переносне (figurative) значення. Він наводить наступні приклади, що ілюструють ці два типи:

- She put down the book. (literal);

- The army put down the rebellion. (figurative) [12, c. 773].

Ми погоджуємося, що іноді дуже важко визначити різницю між literal та semi-literal фрразовими дієсловами. У своєму дослідженні ми багато разів зустрілися з таким явищем, коли важко достеменно стверджувати, до якої саме групи (literal або semi-literal) віднести те чи інше дієслово.

Наприклад:

- tear up [2, c. 36] - "destroy something such as a piece of paper or cloth by pulling it into pieces" [22] (розірвати на шматки).

R. Singh стверджує, що сполучення (комбінація) дієслова та частки може вважатися фразовим, якщо це сполучення має значення яке або «очевидне», тобто буквальне, таке як take off (I took off my jacket) або «дуже ідіоматичне» (highly idiomatic), як в реченні «The plane took off». Таким чином, цей дослідник також розподіляє всі фразові дієслова на дві підгрупи за одними і тими ж ознаками.

Деякі граматисти, такі як M. Kollen стверджують, що фрразові дієслова - це лише ті словосполучення (комбінації), що утворюють ідіому, тобто фразу, значення якої не може бути зрозумілим зі значень їі складових. Це є семантична точка зору, що фокусується здебільшого на значенні вислову $[13$, с. 35]. Але на нашу думку, таке визначення не $є$ достатньо повним, так як в англійській мові можна знайти багато фразових дієслів, значення складових яких може дати уявлення про значення дієслова в цілому.

Наприклад:

- move around [2, с. 9] - go from one place to another (пересуватися);

- pick up [2, c. 6] - "to lift someone or something up from a surface" [22] (піднімати).

3 точки зору семантики вчений-лінгвіст B. Fraser зазначає, що фразові дієслова можуть бути згруповані згідно їх семантичних ознак. Таким чином, фразові дієслова, що мають спільні значення можуть бути віднесені до однієї групи [14, с. 12].

Більшість фрразових дієслів є багатозначними, а деякі навіть мають більш ніж 10 значень. Лінгвісти J. Seidl та W. McMardie вважають, що «будь-яка комбінація може мати декілька ідіоматичних значень, в залежності від слів, що йдуть попереду або після неї» [15, с. 114] Ми ж у своєму дослідженні намагалися розглядати фразові дієслова у тому значенні, що зустрічаються в романі, тому вони мають здебільшого одне значення. 
Фразові дієслова варіюються у ступені своєї ідіоматичності, тобто ідіоматичність - це градієнт. Іноді для того, щоб зрозуміти значення такого дієслова, достатньо розглянути його в контексті, а іноді навіть контекст не дає можливості визначити його значення до тих пір, поки не звернутись до словника чи спеціальної літератури, присвяченої ідіомам чи фразовим дієсловам.

Це підтверджує і лінгвіст Т. McArthur, який стверджує, що окрім буквального та/або ідіоматичного значення деякі фразові дієслова мають безліч різних значень, що залежать від контексту [12, с. 773774]. Наприклад, фразове дієслово bring in. Буквально: "The milkman brought in the milk" (фразове дієслово має буквальне значення «занести»). Ідіоматично: "The prime minister brought in a new policy." (фразове дієслово має ідіоматичне значення «внести до розгляду».) [12 , с. 773-774]. На думку дослідника, особливо уміло ідіоматичне та буквальне значення розкривають зміст жартів та смішних малюнків. Читаючи деякі жарти або побачивши смішні ілюстрації з підписами, що містять фразові дієслова, у людей виникає плутанина, яке саме значення фразового дієслова мав на увазі автор. Ця плутанина розкриває зміст жарту. Наприклад: " "Put the kettle on!" "Oh, it suits you."” (Жарт бере за основу двозначність дієслова put on, яке може мати значення "ставити", в даному випадку - на вогонь; та значення "одягати") [12, с. 773-774].

\section{III Результати}

Розглянувши всі вищезазначені класифікації, ми дійшли висновку, що найбільш повною та цікавою є класифікація за M. Celce-Murcia та D. Lassen-Freeman (1999).

Вони розподіляють всі фразові дієслова на три групи, перша і остання з яких є більш-менш представленою у інших класифікаціях, а друга, яку вони називають semi-literal phrasal verbs, є найбільш повною та детальною з-поміж усіх розглянутих нами підходів. Ця класифікація була взята нами за основу у нашому дослідженні.

Як вже зазначалося, фразове дієслово - це сполучення дієслова та так званого післялогу (прийменника або прислівника), що уявляє собою семантичну єдність. Щодо визначення статусу другого компоненту або післялогу, то існують дві основні точки зору.

Прибічники першої точки зору відносять другий компонент фразового дієслова до однієї з вже існуючих частин мови: прийменників (Smith,1962), часток (Bolinger), післялогів, прийменників та часток (L. G. Alexander, 1988) або прислівників (A. Sroka, 1972).

Що ж до другої теорії, то в цьому випадку, дослідники вважають, що 2-й компонент - це особливі елементи і називають їх так: семантизаторами (Н. Б. Карачан, 1972), постпозитивами (О.В.Кунін, 1984), поствербами (И. А. Клиюнайте, 1989) або адвербами (Л.В. Шведова, 1997).

О. В. Кунін вважає, що післялог є словом, оскільки поєднується з дієслівним компонентом, що має словозмінну парадигму [10, с. 308]. «...Післялог змінює, уточнює, доповнює значення дієслова, до якого він відноситься» [16, с. 47].

Ряд філологів стверджує, що 2-й компонент фразового дієслова має значення, тому що, щоб поєднатися 3 дієсловом, післялог обов'язково повинен мати необхідне значення. В іншому випадку, не було б необхідності їх приєднувати [17, с.17]. «Післялог впливає на семантику дієслова, змінюючи її. Дієслово та післялог семантично послаблені і значення цілого не виводиться зі значень складових.» [18, c. 30].

Прибічники обох точок зору вказують на подвійний характер другого компоненту фразового дієслова. Він пояснюється специфікою англійської короткослівної лексики. Радянський фрілологгерманіст В. Я. Плоткін стверджує: «Короткі одноморфемні слова характеризуються високою поліфункціональністю і слабко закріплені за частинами мови» [19].

Адвербальними післялогами радянський лінгвіст І. Є. Анічков [20, с. 125] називає особливий розряд постпозитивних прислівників (up, out, off, і так далі), що складаються з одиниць, яким властиві наступні родові ознаки прислівників :

- здатність приєднуватися до дієслів, прикметників і інших прислівників, рідко - до іменників, іноді - до словосполучень і пропозицій;

- уточнення і доповнення їх значень; 
- вони разом з небагатьма наявними в мові постпозитивними прислівниками, займають положення (за винятком випадків стилістичної інверсії) тільки після слова або ряду слів, до якого вони приєднуються.

Адвербальні післялоги, на думку Анічкова [20, с. 129], мають ще і наступні видові або відмітні ознаки.

Вони здатні, приєднуючись до слів або до рядів слів, складати з ними разом більш-менш тісні і стійкі змістові, синтаксичні і фонетичні цілі і складні одиниці, в яких виконувана або обставинна функція часто настільки ослаблена, що не можна бачити в післялогах відносно самостійні обставини.

На відміну від іншого постпозитивного говору, поєднуючись з дієсловом, що приймає пряме доповнення, післялоги можуть займати і зазвичай займають місце після дієслів. Вони так само відділяють дієслово від прямого додатку.

Наприклад: turn out the light; put on your coat. АЛЕ: hold your head still; carried the lead far; take my luggage $[20$, c. 129].

А. А. Керлін називає післялог словоутворюючим незмінним елементом, який стоїть після дієслова та утворює з ним єдине змістове ціле («составной глагол»). Втративши своє реальне значення або зберігши його у ослабленому вигляді, післялог змінює, уточнює, доповнює значення дієслова, до якого він відноситься [21].

Підсумовуючи все вищезазначене, слід сказати, що ми вважаємо другий компонент фразового дієслова прислівником або прийменником. Хоча він і являється частиною фразового дієслова, але він привносить свої нюанси у значення фразових дієслів, що входять до його складу, а інколи навіть повністю змінює його значення до невпізнанності, що і робить фразові дієслова унікальнім та самобутнім явищем англійської мови.

Дослідивши різноманітні погляди лінгвістів на поняття фразового дієслова, можемо сказати, що ми розглядаємо фразові дієслова як одновершинні фразеологічні одиниці, що складаються з дієслова та прислівника або прийменника, які впливають на значення дієслова , а в деяких випадках більш повно розкривають нюанси дії. Вони допомагають автору більш виразно та точно передавати свої думки. Саме за допомогою фразових дієслів текст стає більш емоційно забарвленим, що робить його привабливішим для читача.

\section{IV Обговорення}

Семантика фразових дієслів роману була виконана за класифікацією M. Celce-Murcia та D. Lassen-Freeman (1999). Згідно якої фразові дієслова розділяються на три групи:

Дієслова, що входять до першої групи (Literal phrasal verbs), зберігають своє основне значення, а також прислівник чи прийменник вживається у одному зі своїх буквальних значень. Звичайно, такі дієслова є найпростішими для розуміння та вивчення.

У нашому дослідженні до цієї категорії входять фразові дієслова, що складаються з дієслова та прийменника, що вказує на напрямок дії (out, down, away, up, through).

Методом суцільної вибірки було відібрано 146 фразових дієслова з твору письменника Дж. Д. Селінджера «Ловець у житі» (1951). Серед них 33\% (48 дієслів) належать до категорії «Nonidiomatic phrasal verbs», тобто до таких, значення яких можна дізнатися, проаналізувавши значення їх складових. Такі дієслова зазвичай складаються з дієслова та прийменника, що вказує на напрямок дії. До таких прийменників у романі, що розглядається, відносяться out, from, back, at, up, down, over, in, around, onto, away, off та інші. Наприклад: come out, look at, come back, pass by, put down, walk around та багато інших.

Друга категорія обраної нами класифікації має назву «Aspectual phrasal verbs» містить дієслова, значення яких складніше визначити, у порівнянні з тими, що належать до першої групи. Для визначення значення таких дієслів замало знати значення їх складових. Такі дієслова можуть містити або дієслово, або частку які вжиті не у буквальному значенні. Дуже часто дієслова з цієї категорії містять частку, що вносить нюанс значення дії. У цій групі було знайдено приклади для ілюстрації наступних підкатегорій:

- дієслова, що мають значення початку дії та містять частки up, off або out (наприклад: start off);

-дієслова, що містять частку on або іп та вказують на початок дії (наприклад: turn on); 
-дієслова, що вказують на продовження діяльності за допомогою часток on або along (наприклад, come on);

-дієслова, що містять частку around та вказують на певну відсутність мети (наприклад, sit around);

-дієслова, що вживаються з часткою up, out або down, які вказують на довершеність дії (наприклад: tear up, burn down aбo laugh off );

-дієслова, що містять частку over та вказують на завершеність дії (наприклад: come over);

- дієслова, що містять частку back з нюансом завершеності дії (наприклад: get back);

Окрім вже запропонованих науковцями категорій, нам здалось доцільним доповнити цю групу ще одним нюансом значення. Таким чином, була введена підкатегорія, що носить назву telicity, до якої увійшли фразові дієслова зі значенням певної завершеності дії. До таких дієслів можна віднести stop by. В цілому, друга група містить 52 фрразових дієслова, що становить 36 \% від загальної кількості відібраних дієслів.

Нарешті третя група, яка має назву «ldiomatic phrasal verbs», містить 46 дієслів (31\% від загальної кількості). Остання група містить дієслова, значення компонентів яких не впливає на значення в цілому. Тут ми бачимо різноманіття часток, які вживаються з дієсловами. Причому зазвичай ні частки, ні дієслова не зберігають своє буквальне значення. Саме такі фразові дієслова урізноманітнюють мову автора роману, а інколи навіть передають неофіційний стиль спілкування та думок головного героя.

\section{V Висновки}

Розглянувши вищезазначені класифікації фразових дієслів за семантичним принципом, ми дійшли висновку, що найбільш повною та детальною є класиффікація за M. Celce-Murcia та D. LassenFreeman (1999). Дані лінгвісти розподіляють всі фразові дієслова на три групи, перша і остання з яких $є$ більш-менш представленою у інших класифікаціях, а друга, яку вони називають Aspectual phrasal verbs, $\epsilon$ найбільш повною та детальною з-поміж усіх розглянутих нами підходів. Ця класифікація була взята нами за основу у нашому дослідженні. Крім того, треба зазначити, що під час аналізу фразових дієслів, що були знайдені в романі, нами були внесені деякі доповнення у вищезазначену класифрікацію. Доповнення вже існуючої класифікації підкатегорією, отримала назву telicity, до якої увійшли фразові дієслова зі значенням певної завершеності дії. В цілому, друга група містить 52 фразових дієслова, що становить 36 \% від загальної кількості відібраних дієслів.

\section{Бібліографічні посилання}

[1] Povey J. Phrasal Verbs and How to Use Them. Учеб. Пособие. М. : Высшая школа, 1990. 176 р.

[2] Salinger J. The Catcher in the Rye. Penguin books, 1994. 192p.

[3] Голубкова Е.Е. Фразовые глаголы движения (когнитивный аспект) : М.: ГЕОС, 2002. 134 с.

[4] Bolinger, D. The Phrasal Verb in English. Harvard University Press. Cambridge Massachusetts, 1971. 205 p.

[5] Григорьев С. В. Фразовые глаголы : Учебно- справочное пособие. СПб.: КАРО, 2003. 272 с.

[6] Quirk R. A comprehensive grammar of the English language. New York: Longman World Publishing Corporation, 1985. $1779 \mathrm{p}$.

[7] Palmer F. R. The English verb. New York: Longman Group Limited, 1974. 269 p.

[8] Смирницкий А. И. Лексикология английского язика. М. : Издательство литературы на иностранных язиках, 1956. 260 c.

[9] Кунин А. В. Английская фрразеология. М. : Высшая школа, 1970. 344 с.

[10] Кунин А. В. Курс фразеологии современного английского языка. М. : Высшая школа, 1996. 381 с.

[11] Celce-Murcia Marrianne and Diane Lassen-Freeman The grammar book. An ESL/EFL teacher's course. Boston: Heinle \&Heinle,1999. $854 \mathrm{p}$.

[12] McArthur T. The Oxford companion to the English language. Oxford/New York: Oxford University Press, 1992.1124 p.

[13] Kollen M. and Funk R. Understanding English grammar. $5^{\text {th }}$ ed, Boston: Allyn and Bacon Press, 1998. 464 p.

[14] Fraser B. The Verb-particle Combination in English. New York: Academic Press,1976.

[15] Seidl J. and McMardie W. English Idioms and how to use them.UK: Oxford University Press, 1978. 272 p.

[16] Арнольд И. В. Лексикология английского язика. М. :1985.

[17] Гурский С. Е. The idiomatic heart of English language. Львов,1975.

[18] Елисеева В. В. Лексикология английского языка. Спб, 2003.

[19] Плоткин В. Я. Грамматические системы в английском языке. Кишинев, 1975.

[20] Аничков И. Е. Английские адвербиальные послелоги: Дисс. ... докт. филол. наук. М., 1947. 536с. 
[21] Керлин А. А., Кузнец М. Д. Составные глаголы в современном английском языке. Л.: Учпредизд, Ленинградское отделение, 1956.

\section{References}

[1] Povey, J. (1990). Phrasal Verbs and How to Use Them. Ucheb. Posobye / Jane Povey. M. : Vusshaia shkola, 176 p.

[2] Salinger, J. (1994). The Catcher in the Rye. Penguin books, $192 \mathrm{p}$.

[3] Holubkova, E. E. (2002). Frazovue hlaholu dvyzhenyia (kohnytyvnui aspekt). HEOS, Moscow, Russia, 134 p. [in Russian]

[4] Bolinger, D. (1971). The Phrasal Verb in English. Harvard University Press. Cambridge Massachusetts, 205 p.

[5] Hryhorev, S. V. (2003). Frazovue hlaholu : Uchebno- spravochnoe posobye. KARO, SPb, Russia, 272 p. [in Russian]

[6] Quirk, R. A (1985). Comprehensive grammar of the English language. New York: Longman World Publishing Corporation, $1779 \mathrm{p}$.

[7] Palmer, F. R. (1974). The English verb. New York: Longman Group Limited, 269 p.

[8] Cmyrnytskyi, A.Y. (1956). Leksykolohyia anhlyiskoho yazyka. Yzdatelstvo lyteraturu na ynostrannukh yazykakh, Moscow, USSR, 260 p. [in Russian]

[9] Kunyn, A. V. (1970). Anhlyiskaia frazeolohyia. Vysshaia shkola, Moscow, USSR, 344 p. [in Russian]

[10] Kunyn, A. V. (1996). Kurs frazeolohyy sovremennoho anhlyiskoho yazuka. Vysshaia shkola, Moscow, Russia, 381 p. [in Russian]

[11] Celce-Murcia, Marrianne, Lassen-Freeman, Diane (1999). The grammar book. An ESL/EFL teachers course. Boston: Heinle \&Heinle, $854 \mathrm{p}$.

[12] McArthur, T. (1992). The Oxford companion to the English language. Oxford/New York: Oxford University Press, $1124 \mathrm{p}$.

[13] Kollen, M., Funk, R. (1998). Understanding English grammar.5th ed, Boston: Allyn and Bacon Press, 464 p.

[14] Fraser, B. (1976). The Verb-particle Combination in English. New York: Academic Press.

[15] Seidl, J., McMardie, W. (1978). English Idioms and how to use them.UK: Oxford University Press, 272 p.

[16] Arnold, Y. V. (1985). Leksykolohyia anhlyiskoho yazyka. Moscow, USSR. [in Russian]

[17] Hurskyi, S. E. (1975). The idiomatic heart of English language. Lvov.

[18] Elyseeva, V. V. (2003). Leksykolohyia anhlyiskoho yazuka. Spb, Russia. [in Russian]

[19] Plotkyn, V. la. (1975). Hrammatycheskye systemu v anhlyiskom yazuke. Kyshynev, USSR. [in Russian]

[20] Anychkov, Y. E. (1947). Anhlyiskye adverbyalnue poslelohy: Dyss. dokt. fylol. nauk. Moscow, USSR, 536 p. [in Russian]

[21] Kerlyn, A. A., Kuznets, M. D. (1956). Sostavnue hlaholu v sovremennom anhlyiskom yazuke. Uchpredyzd, Lenynhradskoe otdelenye, Leningrad, USSR. [in Russian]

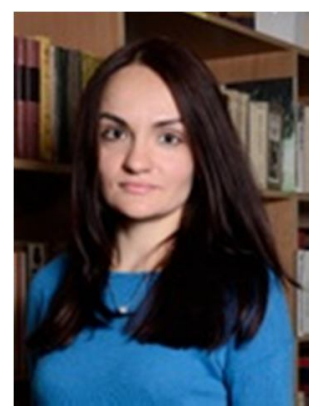

\section{Шокарьова Наталія Сергї̈вна.}

Вчитель вищої категорії, КЗ «Харківська спеціалізована школа №11», Вул. Василя Мельникова, 7, Харків, Харківська область, Україна, 61000.

Tel. 098-656-85-55. E-mail: shokareff@gmail.com

\section{Shokarova Nataliia Serhiivna.}

Teacher, Kharkiv Specialised School № 11,

7 Vasylia Melnykova Street, City, Country, Ukraine, 61000.

Tel. 098-656-85-55. E-mail: shokareff@gmail.com

ORCID: 0000-0001-5650-9955

\section{Citation (APA):}

Shokarova, N. (2019). Linguistic aspects of studying phrasal verbs. Engineering and Educational Technologies, 7 (2), 50-58. doi: https://doi.org/10.30929/2307-9770.2019.07.02.05

\section{Цитування (ДСТУ 8302:2015):}

Шокарьова Н. С. Лінгвістичні аспекти вивчення фразових дієслів / Інженерні та освітні технології. 2019. Т. 7. № 2. С. 50-58. doi: https://doi.org/10.30929/2307-9770.2019.07.02.05

Обсяг статmі: $\quad$ сторінок - 9 ; умовних друк. аркушів - 1,304. 